\title{
21
}

\section{Stone Sources and Petrology of Kuk Swamp Artefacts}

\author{
Marjorie Sullivan, John Burton, David Ellis, Jack Golson \\ and Philip Hughes
}

\section{Stone artefacts and manuports}

No stone occurs naturally in the Kuk swamp deposits, and any stone found there has to have been carried in by people. Possible exceptions are the rocks of the volcanic debris avalanche from Mt Hagen, which reached the southern margins of Kuk Swamp (see Chapter 6, section 'Kuk Swamp in its local setting' and Fig. 6.5). These rocks formed mounds that protruded through the swamp surface. However, since the mounds are generally mantled with tephra and the rocks seldom exposed, they would have been a minor source of supply, if utilised at all.

Stone was brought to the swamp for various purposes: for manufacture of or use as stone artefacts; as 'cooking stones' or heat retainers in cooking ovens; or for other, unknown purposes. This latter group of stone pieces with no discernible use makes up what are called 'manuports', meaning 'carried in by hand'. They could have been used as ammunition in slingshots, which are now mainly used for killing birds, as heavy objects to deliver blows in killing animals, as blocks to sit or sleep on, as objects associated with ritual or as potential sources for artefact manufacture. All had been brought into the area.

Of major archaeological interest are the stone artefacts found in the swamp. They comprise ground and polished axes (for a definition see footnote 1 of Chapter 20), a variety of flaked artefacts, grinding implements and a drilled and pecked piece from a club head. Hearth and cooking stones mark places of domestic activity, including dwellings.

\section{Stone sources for Kuk Swamp}

Kuk Swamp lies within a broad basin in the Wahgi River floodplain. In the immediate surroundings of the swamp there is no shortage of excellent quality stone for human use. The geology and landforms of the area have been summarised by Löffler (1977: 26-27). The Wahgi River tributaries drain parts of two structural regions: the New Guinea Mobile Belt, which comprises ancient rocks that have been block-faulted and folded and intruded by old to very recent volcanics; and the Kubor Anticline, with heavily folded and deformed 
sequences of Palaeozoic basement, igneous and metamorphic rocks and non-metamorphosed sedimentary rocks. Kuk is surrounded by high, steep volcanic mountains and ridges formed on these structural units, which are drained by a network of gravel-bed streams.

Rocks within the Wahgi catchment above Kuk, identified from field observations and geological mapping (Bain, Mackenzie and Ryburn 1975) include: intrusive and volcanic igneous rocks ranging from basic to acidic, and comprising intrusive gabbro, diorite, granodiorite, tonalite and pegmatite together with a range of volcanics, particularly basalt; mixed sedimentary rocks including lithic sandstones/greywackes, tuffaceous sandstones, shales, siltstones, limestones and dolomite; and a wide range of metamorphic rocks including schists, phyllites, gneisses, metavolcanics, hornfels, anorthosite and serpentinite.

Boulders and cobbles from the beds of the Wahgi, Gumants, Guga and other rivers within a few kilometres of Kuk therefore include a very wide range of rock lithologies, many of which were used for specific purposes. In a sample of cobbles collected in 1975 from the Wahgi River immediately below Kuk, Sullivan identified: pink and grey granitic rocks, mainly granodiorites and pegmatites; acidic, intermediate and basic volcanic rocks-rhyolites to basalt-many of the basics being very rounded with deeply weathered yellow-brown cortex; sub-rounded and fractured high-grade metamorphic rocks - schists to gneisses - mainly quartz-rich and containing prominent mica; metasediments, mainly metamorphosed greywackes, hornfels and quartzites; and limestone. Of 107 cobbles inspected the percentages were:

- Volcanics (46 per cent)

- Acid igneous intrusives (32 per cent)

- High grade metamorphics (6 per cent)

- Metasediments (mainly meta-greywacke, and hornfels) (14 per cent)

- Limestone (2 per cent)

We have already mentioned the mounds in the major debris avalanches from Mt Hagen that shaped the local landscape. They contain lava - mainly basalt, but also more acidic volcanicsand other stone collected by the high-energy mudflows and occur both within and adjacent to the margins of the swamp. It was noted that generally the softer sedimentary rocks such as shales and indurated mudstones, and the vesicular volcanic rocks common in the lahar mounds do not survive as cobbles in the high-energy streams.

\section{Stones used as heat retainers in cooking}

In 1985, at Golson's request, Alan Watchman, a consultant geologist and geoarchaeologist, recently graduated from ANU, carried out a petrographic examination of 12 stones identified by local villagers as suitable for use as ovenstones, i.e. heat retainers in earth ovens. They had been collected by Golson from three rivers at or near Kuk (see Fig. 23.2). There were five from the Guga at Kenta, a Kuk hamlet; four from the Wahgi near the southeastern corner of Kawelka land; and three from the Gumants at the road bridge near the Gumanch Plantation (see Fig. 22.1). Later David Ellis (1994), head of Geology at ANU, compared these rocks with 19 others described by local people as unsuitable for use in ovens when collected by Golson at the same times and places as those they identified as ovenstones. 
With the exception of one from the Wahgi (\#4), all of the heat-retaining stones are fine-grained basaltic lavas. Watchman (1985) identified them as basalt, weakly metamorphosed basalt, vesicular basalt or ignimbrite/tuff. They ranged from glassy to finely crystalline and all contained basic igneous minerals, like plagioclase feldspars and pyroxenes, as well as secondary metamorphic minerals such as epidote and albite.

Wahgi \#4 is a fine-grained metamorphosed sedimentary rock dominated by even-grained quartz, with biotite and muscovite (sericite), which Watchman described as hornfels. It was heat-affected during formation by proximity to an igneous intrusion. Its even, non-foliated structure and the absence of hydrous metamorphic minerals would have made it suitable as an ovenstone, as would its slight recrystallisation, which produced interlocking grains that enhanced its ability to resisted fracturing when heated.

Ellis (1994) concluded that the favoured rock for ovenstones is fine-grained basaltic lava flow material. While the Hagen Volcanics are an obvious source, there are numerous others. Of the 19 stones pronounced by local villagers to be unsuitable for use as oven stones, Ellis said that only one, a fresh volcanic rock labelled Rock R, was ever likely to have been so used. The 18 unsuitable rocks belonged in the main to a wide range of very fine- to very coarse-grained basic to acidic igneous rocks, some of them metamorphosed. A few were sedimentary rocks.

\section{Stone used for artefacts}

\section{Flaked stone artefacts}

In Chapter 20, Fullagar describes the flaked artefacts from Kuk as including flakes, cores and utilised fragments. These artefacts are listed by raw material in Table 21.1.

There is no evidence that people in the highlands traded or imported finished flaked artefacts. Instead they selected cobbles or blocks of rock available locally for flaking. The stone materials that were chosen generally did not tend to shatter along fracture planes inherent in the rock. The flaked artefacts at Kuk were all made on coherent fine-grained or crystalline rocks which distributed the force of hitting or flaking uniformly throughout the rock mass. With such materials, the flaking process can be controlled to produce the required shape of flake or core.

The petrology/lithology of a sample of flaked stone artefacts from Kuk Swamp was examined by Ellis (1994) and his terminology has been refined here to reflect the following petrological descriptions appropriate to the Mount Hagen area.

Chert is a term that refers to very fine-grained rock composed mainly of cryptocrystalline quartz. Cherts are generally pale-coloured siliceous rocks. Because the term 'chert' is used loosely, material that has been so classified may be of a kind with an origin that technically belongs to one of the rock types described below. Material loosely described as chert could be altered rock that originated as material ejected from a volcano (ignimbrite) or slightly indurated very fine-grained sedimentary rocks (siltstones or mudstones). It might be true chert formed as precipitated or replaced silica in altered limestone or dolomite. In its finest translucent form chert may be banded and referred to as agate (or another gemstone term).

Ignimbrite is material ejected from a volcano that has cooled rapidly and which varies greatly in composition and form. The ignimbrite used for artefacts in the study area is fine-grained or glassy pale-coloured siliceous rock. It is chiefly a fine-grained rhyolitic tuff formed mainly of glass particles (shards) in which crystals of feldspar and quartz, as well occasionally as altered hornblende, are embedded. 
Acid (felsic) volcanic is fine crystalline igneous rock that flowed or was ejected (as an airfall deposit) from a volcanic eruption and cooled quickly. Chemically such rocks have the composition of granite/tonalite or granodiorite. If they are flow-banded, they are referred to as rhyolite or trachyte.

Basic (mafic) volcanic is fine crystalline igneous rock that flowed or was ejected from a volcanic eruption and cooled quickly. Chemically such rocks have the composition of gabbro or diorite, if solidified as an intrusive igneous rock, or of a basalt, if an extrusive igneous rock.

Volcanic glass is a glass naturally produced by the cooling of molten lava, or some liquid in it, too rapidly to permit crystallisation. Basic volcanic glass is black, dark brown or greenish and as an extensive outcrop is referred to as tachylite. Acidic volcanic glass or obsidian is less frequent and is commonly dark brown to yellow or cream. The light-coloured form may also be classed as ignimbrite. It is not possible to distinguish between the darker-coloured acidic and basic forms in hand specimen.

Mudstone or siltstone is very fine-grained sedimentary rock, rich in silt and clay particles. Commonly mudstones were hardened or indurated by heat from a nearby igneous source or by secondary silicification as silica-rich water moved through initially soft rock. When hardened, they are suitable for flaking. When metamorphosed under high pressure they can be transformed into slate.

Table 21.1 Raw materials for flaked artefacts at Kuk.

\begin{tabular}{|c|c|c|c|c|c|c|c|}
\hline \multirow{2}{*}{$\begin{array}{l}\text { Cultivation } \\
\text { phase }\end{array}$} & \multirow{2}{*}{$\begin{array}{l}\text { Total no. } \\
\text { flaked } \\
\text { artefacts }\end{array}$} & \multicolumn{6}{|c|}{ Raw material for flaked artefacts } \\
\hline & & $\begin{array}{c}\text { Chert } \\
\text { +agate }\end{array}$ & Ignimbrite & $\begin{array}{c}\text { Acid } \\
\text { volcanic }\end{array}$ & $\begin{array}{c}\text { Basic volcanic/ } \\
\text { basalt }\end{array}$ & $\begin{array}{c}\text { Volcanic } \\
\text { glass }\end{array}$ & $\begin{array}{l}\text { Indurated } \\
\text { mudstone }\end{array}$ \\
\hline Phase 1 & 3 & 1 & 2 & & & & \\
\hline $\begin{array}{l}\text { Between } \\
\text { Phases } 1 \text { \& } 2\end{array}$ & 2 & 1 & & 1 & & & \\
\hline Phase 2 & 6 & 5 & 1 & & & & \\
\hline Phase $2 / 3$ & 1 & 1 & & & & & \\
\hline Phase 3 & 1 & & & & & & 1 \\
\hline Phase 4 & 1 & & & 1 & & & \\
\hline Phases 4-61 & 5 & 2 & & & 1 & 1 & 1 \\
\hline Phase 6 & 11 & 8 & & 3 & & & \\
\hline
\end{tabular}

Source: Data from Tables 20.2, 20.3, 20.4.

Note:

${ }^{1}$ These artefacts came from the garden soil incorporating Phases 4, 5 and 6, but their precise location was uncertain.

The number of flaked artefacts recovered from all but the most recent phase is very low. Fullagar (in Chapter 20) notes that most of the flaked artefacts from that phase are fragments of axes, later reworked. Apart from the fine-textured or glassy basic volcanic materials resulting from such recycling, most of the flaked stone artefacts were made on siliceous rocks, including acidic volcanic materials.

\section{Grinding artefacts}

Rock used for grinding must be abrasive, and necessarily contain large angular grains or crystals that can score other rocks. Coarse sedimentary rocks, slightly weathered intrusive igneous rocks and contorted metamorphic rocks all have such properties, especially if they contain large quartz or fresh feldspar crystals or grains. The 14 grindstone fragments or whole grinding artefacts recovered from Kuk are listed according to cultivation phase in Table 21.2. 
Table 21.2 Grinding artefacts at Kuk.

\begin{tabular}{|l|l|l|}
\hline Cultivation phase & Artefact & Raw material \\
\hline Phase 1 & Handstone pestle & Deformed chlorite schist \\
\hline Between Phases 1 \& 2 & $\begin{array}{l}\text { Lower grindstone/anvil } \\
\text { Mortar rim }\end{array}$ & $\begin{array}{l}\text { Intrusive basic volcanic (gabbro) } \\
\text { Tholeitic basalt }\end{array}$ \\
\hline Phase 2 & $\begin{array}{l}\text { Handstone pounder } \\
\text { Handstone pounder }\end{array}$ & $\begin{array}{l}\text { Weathered basalt } \\
\text { Intrusive acid igneous }\end{array}$ \\
\hline Phase 2/3 & Lower grindstone & Hornblende andesite \\
\hline Phase 3 & Lower grindstone & Acid volcanic breccia \\
\hline Phase 4 & Lower grindstone/anvil & Basalt \\
\hline Phases 4-51 & Grinding stone & Sandstone \\
\hline Phases 4-62 & Handstone & Intrusive acid igneous \\
\hline Phase 5 & Handstone/pounder & Basalt \\
\hline Phase 6 & $\begin{array}{l}\text { Grinding stone } \\
\text { Grinding stone } \\
\text { Grinder/axe butt? }\end{array}$ & $\begin{array}{l}\text { Basic volcanic } \\
\text { Sandstone } \\
\text { Metamorphosed sediment }\end{array}$ \\
\hline
\end{tabular}

Source: Data from Table 20.5.

Notes:

${ }^{1}$ These artefacts came from the garden soil incorporating Phases 4 and 5 but their precise location was uncertain.

${ }^{2}$ These artefacts came from the garden soil incorporating Phases 4, 5 and 6 but their precise location was uncertain.

Golson (2000: 236) has previously claimed that one grinding artefact from Kuk, a probable rim fragment from a stone mortar (K/77/S34), is the oldest of its type found in New Guinea-from some 7000-7500 years ago. The piece was examined by David Ellis and Douglas Mackenzie, an expert on the volcanics of the PNG highlands, to determine its composition and the source of the material from which it was made. The results were unexpected on the basis of composition and inconclusive on that of provenance (Golson 2000: 233-234). A full account is told in Appendix 21.1.

\section{Ground axes and axe quarries}

The discussion so far has dealt with two of the three classes of stone artefacts excavated at Kuk and identified by Fullagar as flaked stones, including flakes, cores and utilised fragments, and grinding and pounding stones, including unmodified plant-processing tools. We have noted that the raw materials from which they were made are all present within the Kuk catchment, with the possible exception of the mortar rim discussed by Noreen Evans and Brent McInnes in Appendix 21.1. For ground stone axes the situation is the reverse, in that for the most part they are not made of local stone, but were imported. This is true both of the small numbers of mainly fragments and flakes of axes recovered in the course of excavation (Table 20.7) and of the large numbers of often whole axes discovered during the establishment of the Research Station, before the start of the archaeological project, and in the course of its operations after that. As a result, they constitute the major stone artefact class at Kuk. Most of the axes were made from metamorphosed sedimentary rocks not found at Kuk, but manufactured from material supplied by specialised quarries and traded in. This indicates that they served to integrate Kuk into the networks of trade and exchange that characterised the Wahgi Valley and neighbouring areas at European contact in the early 1930s, in which axes played a key role. The axes, their sources, their manufacture and their distribution were the subject of a major study in the Wahgi in the early 1980s (Burton 1984), and the discussion here is based on that work. 
Burton (1984: 3) points out that many sources of axe stone in the highlands of Papua New Guinea are known to have been exploited, but the most productive are confined to the Wahgi and the Jimi Valleys, where 'overall output is likely to have run into hundreds of thousands of axes per century'. These were the major sources of the axes found at Kuk (Figure 21.1), where the relevant quarries fall into two main geographic groups: quarries in the Jimi Valley and at the Sepik-Wahgi Divide 20-35 km north to northeast of Kuk; and those in the Wahgi Valley $22-75 \mathrm{~km}$ from east to southeast of Kuk.

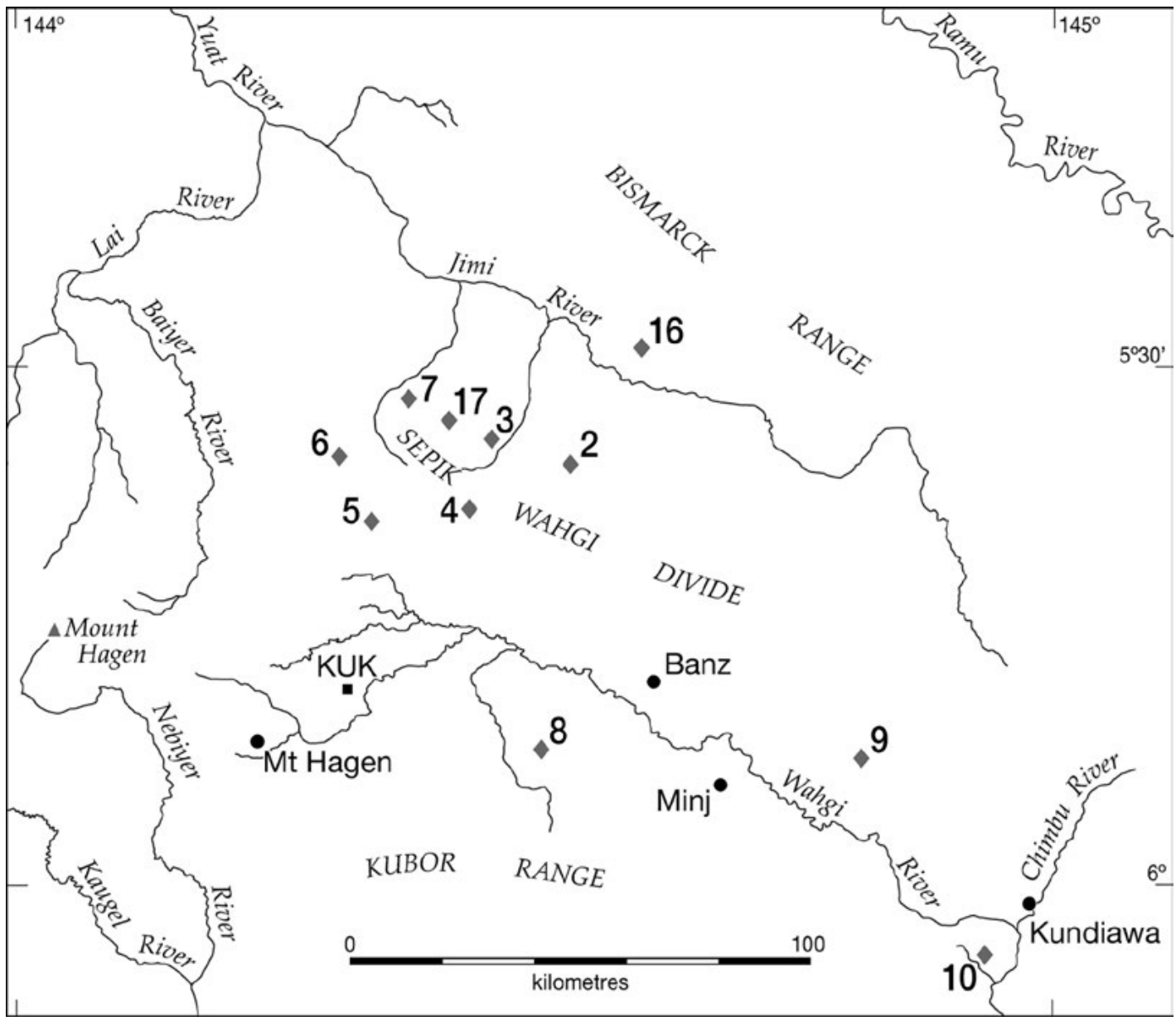

Figure 21.1 Quarries with axes represented at Kuk.

Note the quarries named are part of the listing in Burton (1984: Table 1.1). 2 Tsenga; 3 Ganz River; 4 Mala Gap; 5 Mbulk; 6 Pukl; 7 Yambina/Kraep; 8 Tuman; 9 Kerowagi; 10 Dom gaima; 16 Repeng/Golum; 17 Apin.

Source: Jennifer Sheehan, CartoGIS Services, College of Asia and the Pacific, ANU.

\section{Axe distributions at Kuk}

As with the wooden artefacts discussed in Chapter 19, most axes were found when Kuk Swamp was drained from the late 1960s. There was disturbance of the swamp by ditching, building and planting associated with the establishment of the Research Station in 1969 and its initial development in the western part of the property. In 1972, when the archaeological project began, team members were shown the axes and wooden implements found over these years and stored for their interest by its personnel. From 1972, axes were still being found with the continued cultivation of the beds in the established half of the Station. The full range of finds appeared 
again with the beginning of drainage in the eastern half of the Station to allow archaeological investigations to be carried out there. The axe finds up to this date are entered in Table 21.3 under Golson's name because he catalogued them.

Table 21.3 Identification of axes from surface collections in three environments at Kuk.

\begin{tabular}{|c|c|c|c|c|}
\hline Environment & & Collection & Number & Weight (g) \\
\hline \multirow[t]{4}{*}{ Swamp } & & Golson & 37 & 5704.6 \\
\hline & & Gorecki & 20 & 4445.0 \\
\hline & & Burton & 5 & 968.8 \\
\hline & Total & & 62 & $11,118.4$ \\
\hline Dryland & & Gorecki & 24 & 7983.0 \\
\hline \multirow[t]{5}{*}{ Ep Ridge } & & Golson & 4 & 583.6 \\
\hline & & Gorecki & 30 & 5543.2 \\
\hline & & Burton & 13 & 2533.0 \\
\hline & Total & & 71 & 8659.8 \\
\hline & GRAND TOTAL & & 133 & $27,761.2$ \\
\hline
\end{tabular}

Source: Based on Burton (1984: 293-295).

When in 1977 Paul Gorecki began his ethnoarchaeological research at Kuk, into the dynamics of agricultural site and settlement site formation, he moved widely over Kawelka territory (see Fig. 23.2), and made or was given axe finds from different parts within it. It was the same case for John Burton, who came in 1980 and again in 1981 to do fieldwork on axe makers of the Wahgi. Both Kuk and the Wurup Valley, on the other side of the Wahgi River, where Ole Christensen worked in 1973 and 1974 (White et al. 1977), were places that provided large axe collections ideal for the examination of the source areas from which they had been traded and of the relative importance of the different sources in that trade.

Burton (1984: 293-295) lists the weights, lengths and most likely sources of axes from Kuk and its surrounds, in the collections made by Burton, Gorecki and Golson 1972-81 described above. The three environments are the swamp itself, the dryland around its margins and the slopes of Ep Ridge to the north. Axes recovered during excavation work of the archaeological project at Kuk Swamp, over the years 1972-77, were described in a listing by Burton (1984: 296). The data originally presented by Burton have been updated here and are summarised in Tables 21.3 and 21.4. Six of the 144 axes in Burton's original table do not appear in Table 21.3 because they are not from Kuk (K/M/S1, K/M/S3, K/72/S63, K/72/S64, K/76/S24 and K/76/S25). Another five have been removed because their locational/stratigraphic data are sound enough for them to be transferred to Table 21.4, which is based on Burton's original data (Burton 1984: 293-294). These are K/72/S9, K/72/S11, K/74/S27, K/74/S38 and K/75/S193.

If the last of these five is accepted as an axe, it is the oldest from the site, being found near the base of a late Phase 3 ditch. However, Fullagar reports in Chapter 20, section 'Axes', that it is made of a different stone from other axes in the collection and is so weathered that its interpretation as an axe is uncertain. In consequence he considers it no further in his discussion, though he retains it in his table on axes (Table 20.7). We retain it in Table 21.4 because it was seen by Burton (1984: 294), who recorded it as of 'local' rock on hand inspection. 
Table 21.4 Sources of axe fragments from stratified contexts at Kuk.

\begin{tabular}{|c|c|c|c|c|}
\hline Catalogue no. & Findspot & Stratigraphic location ${ }^{1}$ & Weight $(g)$ & Likely source $^{4}$ \\
\hline $\mathrm{K} / 72 / \mathrm{S} 9^{2}$ & \multirow{2}{*}{$\begin{array}{l}\text { During digging of east end of E-W } \\
\text { Rd } 3 \text { south drain at junction with } \\
\text { eastern boundary drain }\end{array}$} & \multirow[t]{2}{*}{$\begin{array}{l}\text { Possibly associated with housing } \\
\text { area here }\end{array}$} & 81.9 & $\begin{array}{l}\text { 5Tsenga } \\
\text { gaima }\end{array}$ \\
\hline $\mathrm{K} / 72 / \mathrm{S} 11^{2}$ & & & 489.8 & ${ }^{5}$ Tuman \\
\hline $\mathrm{K} / 72 / \mathrm{S} 38$ & $\begin{array}{l}\text { During digging of E-W Rd } 3 \text { south } \\
\text { drain at block C7e }\end{array}$ & $400 \mathrm{~mm}$ deep in surface peat & 97.1 & Tuman \\
\hline $\mathrm{K} / 72 / \mathrm{S} 52$ & $\begin{array}{l}\text { During digging of E-W Rd } 3 \text { drains } \\
\text { at junction with N-S Rd } 4\end{array}$ & Base of peat in housing area & 164.3 & c \\
\hline $\mathrm{K} / 72 / \mathrm{S} 94$ & $\begin{array}{l}\text { During digging of E-W Rd } 2 \text { north } \\
\text { drain at SE corner of block C9 }\end{array}$ & $\begin{array}{l}150 \mathrm{~mm} \text { above base of young ditch } \\
\text { close to housing area }\end{array}$ & 104.9 & ${ }^{5}$ Tuman \\
\hline $\mathrm{K} / 72 / \mathrm{S} 98^{3}$ & $\begin{array}{l}\text { Wall of S Boundary } N \text { drain about } \\
80 \mathrm{~m} \text { E of the middle of } \mathrm{N}-\mathrm{S} \text { Rd } 4\end{array}$ & $\begin{array}{l}540 \mathrm{~mm} \text { below surface in base of greasy } \\
\text { organic layer underlying felted peat }\end{array}$ & 78.9 & ${ }^{5}$ Tuman \\
\hline $\mathrm{K} / 72 / \mathrm{S} 102 \mathrm{~A}$ & $\begin{array}{l}\text { During excavation at House } \mathrm{C} \\
\text { at } \mathrm{N} \text { end of block } \mathrm{A9g}\end{array}$ & $\begin{array}{l}\text { In the earlier stage of the house ditch } \\
\text { on } \mathrm{N} \text { side of house }\end{array}$ & 42.7 & A \\
\hline $\mathrm{K} / 72 / \mathrm{S} 109$ & $\begin{array}{l}\text { During excavations at Houses B \& } \\
\text { C at N end of block A9g }\end{array}$ & $\begin{array}{l}\text { Found on spoil heap from the } \\
\text { excavations }\end{array}$ & 40.7 & D \\
\hline $\mathrm{K} / 72 / \mathrm{S} 111^{3}$ & $\begin{array}{l}\text { During excavation of men's House } \\
\text { at } S \text { end of block A9h }\end{array}$ & Bottom of ditch surrounding the house & 54.1 & C \\
\hline $\mathrm{K} / 72 / \mathrm{S} 119$ & \multirow{4}{*}{$\begin{array}{l}\text { During excavation of House } \mathrm{F} \\
\text { at } \mathrm{N} \text { end of block } \mathrm{A9g}\end{array}$} & \multirow[t]{3}{*}{ From soil over house floor } & 42.1 & ${ }^{5}$ Tuman \\
\hline $\mathrm{K} / 72 / \mathrm{S} 120$ & & & 50.5 & C \\
\hline $\mathrm{K} / 72 / \mathrm{S} 121$ & & & 74.0 & ${ }^{5}$ Tuman \\
\hline $\mathrm{K} / 72 / \mathrm{S} 123$ & & 0n floor of house & 37.1 & ${ }^{5}$ Tuman \\
\hline $\mathrm{K} / 73 / \mathrm{S} 60$ & $\begin{array}{l}\text { During excavations between } \\
\text { Houses A \& B at N end of block A9 }\end{array}$ & Topsoil & 67.4 & C \\
\hline $\mathrm{K} / 73 / \mathrm{S} 66$ & $\begin{array}{l}\text { During excavation of House } \mathrm{A} \\
\text { at } \mathrm{N} \text { end of block } \mathrm{A9g}\end{array}$ & From ditch on $\mathrm{S}$ side of house & 95.9 & C \\
\hline $\mathrm{K} / 73 / \mathrm{S} 114$ & $\begin{array}{l}\text { During excavations at house } \\
\text { cut by drain A11a/b }\end{array}$ & Edge of house ditch in block A11b & 67.1 & Mbukl \\
\hline $\mathrm{K} / 74 / \mathrm{S} 27^{2}$ & $\begin{array}{l}\text { In grey clay } 50 \mathrm{~mm} \text { below base } \\
\text { of large young ditch in A10f/g }\end{array}$ & $\begin{array}{l}\text { A10f/g, area of Phase } 5 \text { and } 6 \text { field } \\
\text { activity, garden area }\end{array}$ & 127.5 & ${ }^{5}$ Tuman \\
\hline $\mathrm{K} / 74 / \mathrm{S} 38^{2}$ & $\begin{array}{l}\text { Excavation by Jim Rhoads of field } \\
\text { ditch in block } \mathrm{A} 10 \mathrm{~g}\end{array}$ & $\begin{array}{l}\text { Ditch articulates with early phase of } \\
\text { Simon's Baret and is thus Phase } 5\end{array}$ & 97.1 & ${ }^{5}$ Tuman \\
\hline $\mathrm{K} / 75 / \mathrm{S} 13$ & $\begin{array}{l}\text { During drain digging, } N \text { end } \\
\text { of } C 9 \mathrm{~g} / \mathrm{h}\end{array}$ & $\begin{array}{l}\text { Associated with floor \& ditch of } \\
\text { possible Phase } 5 \text { house }\end{array}$ & 609.2 & Tuman \\
\hline $\mathrm{K} / 75 / \mathrm{S} 20$ & $\begin{array}{l}\text { During drain digging, S end } \\
\text { of }(9 \mathrm{~g} / \mathrm{h}\end{array}$ & $\begin{array}{l}\text { Fill of younger phase of redug surface- } \\
\text { visible house ditch }\end{array}$ & 110.3 & Dom gaima \\
\hline $\mathrm{K} / 75 / \mathrm{S} 50$ & During digging of drain C9d/e & In vicinity of possible house & 46.5 & Local \\
\hline $\mathrm{K} / 75 / \mathrm{S} 64$ & $\begin{array}{l}\text { During digging of } \mathrm{N} \text { end of drain } \\
\mathrm{C} \mathrm{c} / \mathrm{d}\end{array}$ & $\begin{array}{l}\text { Fill of later stage of slightly surface- } \\
\text { visible house ditch }\end{array}$ & 432.0 & ${ }^{5}$ Tuman \\
\hline $\mathrm{K} / 75 / \mathrm{S} 78$ & $\begin{array}{l}\text { During digging of } \mathrm{N} \text { end of drain } \\
\mathrm{C} 9 \mathrm{~b} / \mathrm{c}\end{array}$ & In ditch 3, younger phase & 54.9 & Dom gaima \\
\hline $\mathrm{K} / 75 / \mathrm{S} 193^{2,3}$ & During excavations in block A12e & Base of late Phase 3 ditch & 161.9 & ${ }^{5}$ Local \\
\hline $\mathrm{K} / 77 / \mathrm{S} 38$ & Hed Mound NE quadrant & $\begin{array}{l}\text { In topsoil close to perimeter ditch } \\
\text { of house compound }\end{array}$ & 62.5 & c \\
\hline $\mathrm{K} / 77 / \mathrm{S} 45$ & Hed Mound NW quadrant & $\begin{array}{l}\text { In topsoil, [from plan] within the } \\
\text { perimeter ditch of house compound }\end{array}$ & 54.5 & ${ }^{5}$ Tuman \\
\hline $\mathrm{K} / 77 / \mathrm{S} 47$ & Hed Mound NW quadrant & $\begin{array}{l}\text { In topsoil, [from plan] on line of } W \text { arm } \\
\text { of perimeter ditch where no ditch dug }\end{array}$ & 32.2 & $C$ \\
\hline $\mathrm{K} / 77 / \mathrm{S} 51$ & Hed Mound SW quadrant & $\begin{array}{l}\text { In topsoil, [from plan] just outside S } \\
\text { arm of perimeter ditch }\end{array}$ & 87.4 & ${ }^{5}$ Tuman \\
\hline
\end{tabular}




\begin{tabular}{|c|c|c|c|c|}
\hline Catalogue no. & Findspot & Stratigraphic location ${ }^{1}$ & Weight $(g)$ & Likely source $^{4}$ \\
\hline $\mathrm{K} / 77 / \mathrm{S} 62$ & Hed Mound SE quadrant & $\begin{array}{l}\text { In topsoil, [from plan] just outside } \\
\mathrm{S} \text { arm of perimeter ditch }\end{array}$ & 78.5 & ${ }^{5}$ Tuman \\
\hline $\mathrm{K} / 77 / \mathrm{S} 63$ & Hed Mound NW quadrant & $\begin{array}{l}\text { Layer 2, [from plan] between perimeter } \\
\text { ditch and ditch at } S \text { of men's house }\end{array}$ & 35.9 & Ganz \\
\hline $\mathrm{K} / 77 / \mathrm{S} 64$ & Hed Mound NW quadrant & $\begin{array}{l}\text { Layer 2, [from plan] within area } \\
\text { enclosed by perimeter ditch }\end{array}$ & 76.9 & ${ }^{5}$ Tuman \\
\hline $\mathrm{K} / 77 / \mathrm{S} 66 \mathrm{~A}$ & Hed Mound NW quadrant & \multirow{2}{*}{$\begin{array}{l}\text { Layer 2, [from plan] close to NW corner } \\
\text { of area enclosed by perimeter ditch }\end{array}$} & 109.3 & ${ }^{5}$ Tuman \\
\hline $\mathrm{K} / 77 / \mathrm{S} 66 \mathrm{~B}$ & Hed Mound NW quadrant & & 56.4 & Ganz \\
\hline $\mathrm{K} / 77 / \mathrm{S} 72$ & Hed Mound SE quadrant & $\begin{array}{l}\text { Layer 2, [from plan] outside } S \text { leg } \\
\text { of perimeter ditch near SE corner }\end{array}$ & 80.9 & Ganz \\
\hline $\mathrm{K} / 77 / \mathrm{S} 81^{3}$ & Hed Mound NE quadrant & $\begin{array}{l}\text { Layer 2, [from plan] just inside of } \\
\text { perimeter ditch }\end{array}$ & 108.6 & Ganz \\
\hline $\mathrm{K} / 77 / \mathrm{S} 82$ & Hed Mound NE quadrant & $\begin{array}{l}\text { Layer } 2 \text {, [from plan] just inside E arm } \\
\text { of perimeter ditch }\end{array}$ & 64.9 & A \\
\hline
\end{tabular}

Source: Based on Burton (1984: 296).

Notes:

${ }^{1}$ All entries are Phase 6, except K/75/S193, which is late Phase 3.

${ }^{2}$ These pieces were transferred from Burton's original list (1984: 293-295, summarised in Table 21.3 here), because they proved to be from a known stratigraphic location or association with houses.

${ }^{3}$ These pieces survived the 2003 bushfire to be examined by Fullagar (see Chapter 20).

${ }^{4}$ The sources identified by an uppercase letter are Burton's (1984: 305) 'Unidentified Groups A-D' of Appendix H on infrared spectroscopy of quarries in the study area, but included by him in the jimi Valley group (1984: 215).

${ }^{5}$ Indicates hand identification only, the rest being identified using infrared spectroscopy.

There is in fact little overlap between Burton's (1984: 296) listing of excavated axes at Kuk, which dates from well before the bushfires of 2003 (see Chapter 18), and what remained in the collections as a result of them (Table 20.7). Aside from the possible Phase 3 axe that we have discussed, there are only three pieces and all are associated with Phase 6 . One of these, K/77/S81, survived because, like the Phase 3 piece, it had been removed from the artefact store for study. The other two, K/72/S98 and S111, were found during salvage work after the fire. The other 28 axes of Burton's listing had been lost. Nine axe pieces in Table 20.7 did not appear in the Burton lists, two of them belonging to Phase 5, the other seven to Phase 6. This may be put down to the problems of storage that Golson discusses in Chapter 18, section 'Stone'.

\section{Sourcing stone axes in the upper Wahgi}

While some axes were made on volcanic rocks, most were made on metamorphosed sedimentary rocks with sediments derived mainly from volcanic minerals that ranged from very dark black to green basic minerals to more acidic pale siliceous minerals. These metasedimentary rocks tend to split along cleavage planes.

Like Chappell (1966: 105-106), Burton found that Tuman, black Jimi Valley, light-coloured Tsenga gaima and Dom gaima axes could be identified with confidence through visual inspection. His numerous informants at the Tuman River (Fig. 21.2) were especially helpful in describing the finer differences of the local products. Tuman axes are typically dark olive green in colour with a distinctive patterning revealed by grinding and polishing, usually in the form of lighter green or even white swirls in the stone. Also the 'classic' Tuman axe shape is fatter in cross-section with the sides of planilateral form often left partially ground. The shape is easily seen in Figures 21.2 and 21.3 and other images in Burton (e.g. 1984: Plates 6.1, 6.2, 6.5, 6.6, 6.14). It is also seen in historic photographs such as Frank Hurley's 1923 image of a man demonstrating the sharpening of 
a Tuman blade at Goaribari Island in the Kikori River delta, where an adze style of hafting was in use (Specht and Fields 1984: V.4233). It also made it possible for Ian Hughes (1977), to identify a Tuman axe purchased from local traders in the Torres Strait by those on board HMS Rattlesnake in 1848, and now in the collections of the British Museum (Burton 1984: 229). It was not possible to differentiate between any of the seven Tuman sources. In rare cases, Tuman axes with a dark patination could be confused in hand specimen with the amphibole-rich black axes from the Jimi Valley, especially if they did not have the distinctive shape of the typical Tuman planiform.

Axes made in the Jimi Valley style are flatter and broader, flared at the cutting edge and with the sides of planilateral form almost always ground. This is seen in Figure 21.4 and in other Burton images (e.g. 1984: Plates 6.3, 6.4). Among the Jimi sources only Tsenga gaima axes could be identified visually.

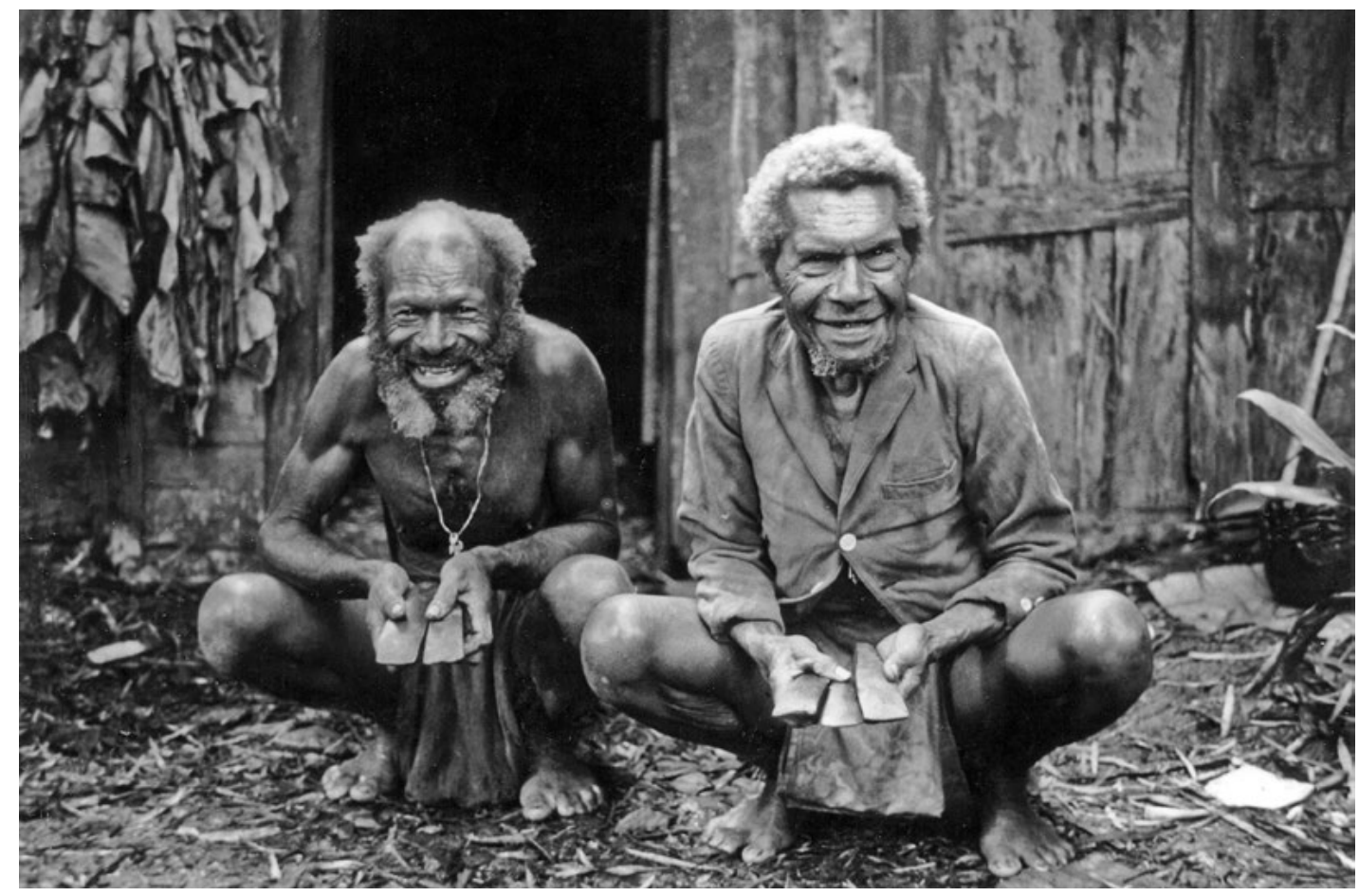

Figure 21.2 Numndi, born about 1900, and Kandel, born about 1896, with Tuman River axes at Orpakl, Tuman River.

Source: Photograph by John Burton, 1980.

After Chappell's (1966: Table 1) identification of the four main mineral constituents of highlands axes as epidote, albite, quartz and tremolite-actinolite, Burton (1984: Chapter 10) experimented with various laboratory techniques to distinguish between the products of different sources. X-ray fluorescence was able to make a clear separation between samples from the Ganz Ketepukla, Tsenga Tingri and Mbukl quarries (Burton 1984: 214, Fig. 10.3), while axes made there are thought to be indistinguishable in hand specimen. Unfortunately, the technique could not be used on a large number of samples because of limited laboratory capacity. Infrared spectroscopy showed that some sources had strong quartz signatures (Tuman, Repeng, Mbukl, Tsenga gaima), while others contained amphiboles, most probably actinolite (Tsenga Tingri, Apin, Yambina and some Ganz), albite (Pukl and most Ganz) and prehnite (Dom gaima). Confusion over the infrared spectra of Tuman and Mbukl axes was possible; examples of the former were common at Kuk, while the latter was a minor source. The Tsenga Tingri, Apin and Yambina sources could not be distinguished using infrared spectroscopy; the first is a major source and the other two minor sources. 


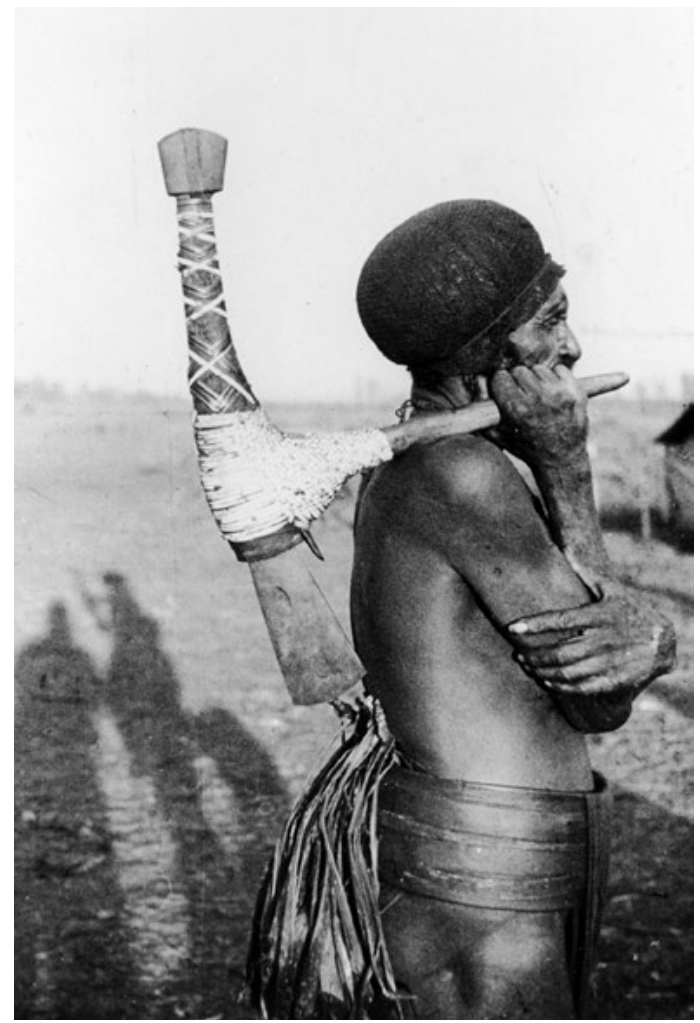

Figure 21.3 Hagener with Tuman axe (from the Michael Leahy Photographic Collection, National Library of Australia).

Source: Burton (1984: Plate 6.8), reproduced with permission.

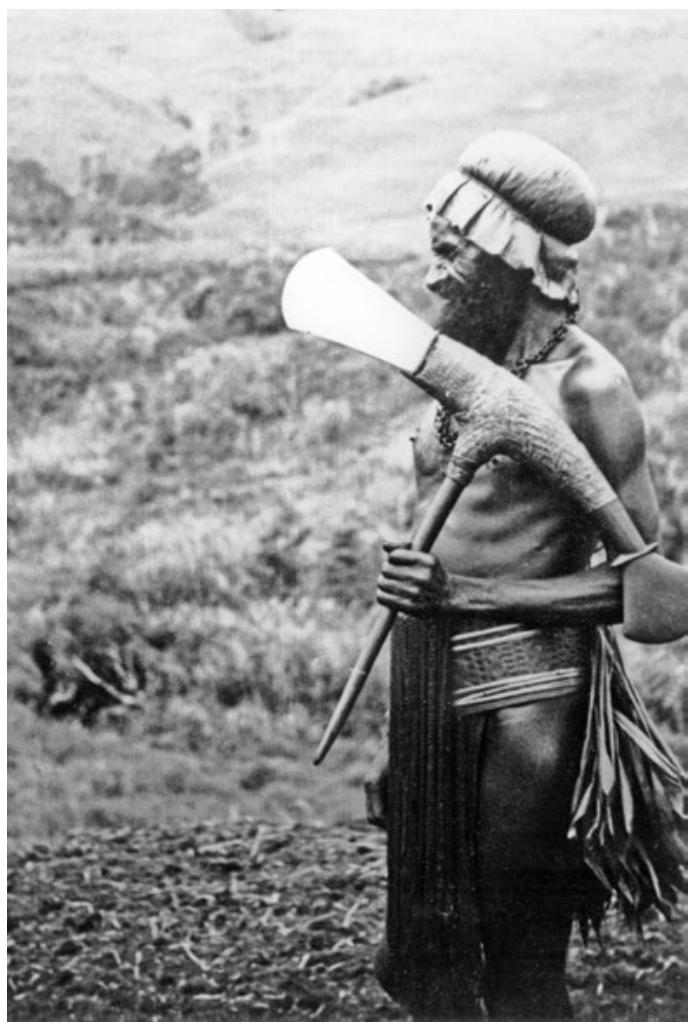

Figure 21.4 Hagener with Jimi axe, probably Tsenga gaima (from the Michael Leahy Photographic Collection, National Library of Australia).

Source: Burton (1984: Plate 6.9), reproduced with permission.

The infrared signatures also revealed four types of source material (labelled A, B, C and D in the tables) that cannot be matched at present with samples recovered from known quarries. In all probability these were axes made from small outcrops at the known Jimi quarries or from distinct sites in the same general area that have not yet been located. Since the major Ganz River source Ketepukla could not be distinguished by the infrared method, it is possible that sources A and/or $\mathrm{C}$ represent Ketepukla or sources of similar composition. For the time being A, B, C and D are classified as Jimi sources, however, this is a conjecture and there is ample scope for future research to elaborate on or refute this claim.

Burton (1984: 211) was able to examine 196 axes of known provenance in Christensen's ethnographic collection from Wurup (presumed to have been lost in the Weston fire described in Chapter 17) and 144 in the Kuk collection (since changed to 133 in Table 21.3). There were 31 fragments (since changed to 36 in Table 21.4) large enough to be drilled for infrared analysis in the collection of stratified finds from Kuk. The provenance of the 169 axes from Kuk is presented in Table 21.5.

Most of the Tuman axes could be identified by eye (Burton 1984: 211). In the Wurup collection there were 78 and 60 at Kuk, after the correction of the original listing for Kuk (Burton 1984: 293-295) with the elimination of one non-Kuk intruder, K/76/S25, and the transfer of two specimens, K/74/S27 and 38, to Table 21.4. A minor type that could often be classified visually was the local (non-quarry) axe (e.g. Wurup 36 and Kuk 15). The latter reduces Burton's listing by two with the elimination of a non-Kuk intruder, K/76/S24, and the transfer of K/75/ S193 to Table 21.4). Two other minor types amenable to visual identification were Tsenga and 
Dom gaima. Three of the former and one of the latter were initially reported by Burton for both Wurup and Kuk. However, the Kuk total for Tsenga gaima here is reduced from three to two with the transfer of K/72/S9 from Burton's listing to Table 21.4.

Despite alterations to the total number of Kuk axes that Burton identified by visual inspection, his conclusion (1984: 211) that a minority of axes in both collections remained to be sourced by infrared spectroscopy still holds. Infrared spectroscopy was used to source 78 axes from Wurup and 55 from Kuk (after the removal of four non-Kuk intruders, K/M/S1, K/M/S3, K/72/S63 and $\mathrm{K} / 72 / 64$ and the transfer of K/72/S11 to Table 21.4). Additional candidates for spectroscopic analysis were 20 of the 31 axe flakes and fragments with locational and stratigraphic information from the archaeological work of the 1970s listed separately by Burton (1984: 296). This list of 31 forms the basis of Table 21.4, but totals 36 because it includes five transfers from Burton's main listing, as described above. One of these additions, $\mathrm{K} / 72 / \mathrm{S} 11$, was also a candidate for spectroscopy.

Besides the Kuk axe fragments that underwent infrared spectroscopy for sourcing, Burton (1984: 211) also put 11 axe pieces from Ole Christensen's Wurup excavations and Mary-Jane Mountain's excavations at Nombe rockshelter in Simbu Province through the same procedure. We address the Wurup results below.

As Burton says (1984: 214-215), the proximity of the Tuman quarries makes it unsurprising that Tuman axes account for more than half the numbers in the Wurup and Kuk collections. Half of the remainder is made up of axes from the Jimi Valley (Ganz, A, B, C, D, Tsenga gaima, Yambina) and the Sepik-Wahgi Divide (Pukl, Mbukl), with the rest consisting of axes of local rock or from more distant sources like Dom gaima and Repeng. Tuman axes are slightly better represented at Wurup than at Kuk (Burton 1984: 216). While axes from Mbukl (Sepik-Wahgi Divide) and Yambina (Jimi Valley) are reported from Kuk, these quarries are not represented at Wurup (Burton 1984: 215). Given the fact that Wurup and Kuk are quite close to one another, less should be read into the small differences in distance to source than the fact that the Kawelka people, the recent owners of the Mbukl quarry (Burton 1984: 213), have strong historical links with Kuk (cf. Chapter 22), so that the appearance of axes from there at Kuk would not be unexpected. Burton found that the Mbukl and Yambina sources could not be identified with confidence (1984: 215 and cf. 206, 212, 213), so that Lampert's earlier claim (Lampert 1972) that as many as 28 per cent of finds from the Warrawau Plantation area at the mouth of the Wurup Valley were from Mbukl cannot be substantiated (1984: 216).

Table 21.5 shows that the axes from surface collections and excavations were broadly similar in provenance, in that most of them were from Tuman and Jimi Valley quarries. The contrast between the size of the excavated axe flakes and that of the surface axes and axe fragments is well illustrated by the weight column.

Burton looked at the possibility of functional differences being reflected in the representation of axes from different sources in the different environments in which they were found at Kuk (1984: 216, Table 10.4). Though numbers are on the low side, chi-square tests on the three most numerous axe types (Tuman axes, locally made axes and Ganz River axes) show that there are no significant differences in their rates of discovery in the dryland gardens, the swamp and on Ep Ridge. The Mubkl axes were all found in the swamp, but the identifications are too uncertain for conclusions to be drawn. 
Table 21.5 Summary of Kuk axe sources.

\begin{tabular}{|c|c|c|c|}
\hline Quarry & Number & $\%$ & Average Weight (g) \\
\hline \multicolumn{4}{|c|}{ Surface axes (mainly whole axes) (taken from Burton 1984: 293-295) } \\
\hline Tuman & 69 & 51.9 & 208.2 \\
\hline Ganz River & 14 & 10.5 & 298.6 \\
\hline Pukl & 5 & 3.8 & 311.7 \\
\hline A & 2 & 1.5 & 274.8 \\
\hline B & 2 & 1.5 & 381.8 \\
\hline C & 6 & 4.5 & 149.1 \\
\hline D & 2 & 1.5 & 119.7 \\
\hline Tsenga gaima & 3 & 2.3 & 574.8 \\
\hline Yambina & 3 & 2.3 & 171.2 \\
\hline Mbukl & 6 & 4.5 & 162.2 \\
\hline Repeng & 1 & 0.8 & 175.6 \\
\hline Dom gaima & 3 & 2.3 & 72.1 \\
\hline Unknown & 1 & 0.8 & 291.7 \\
\hline Local & 16 & 12.0 & 196.2 \\
\hline TOTAL/AVERAGE & 133 & 100 & 242 \\
\hline \multicolumn{4}{|c|}{ Axe fragments from stratified and housing contexts (see Table 21.4) } \\
\hline Tuman & 16 & 44.4 & 164.4 \\
\hline Ganz River & 4 & 11.1 & 70.5 \\
\hline A & 2 & 5.6 & 53.8 \\
\hline C & 7 & 19.4 & 75.3 \\
\hline D & 1 & 2.8 & 40.7 \\
\hline Tsenga gaima & 1 & 2.8 & 81.9 \\
\hline Mbukl & 1 & 2.8 & 67.1 \\
\hline Dom gaima & 2 & 5.6 & 137.8 \\
\hline Local & 2 & 5.6 & 104.2 \\
\hline TOTAL/AVERAGE & 36 & 100 & 88.4 \\
\hline \multicolumn{4}{|c|}{ All axes combined } \\
\hline Tuman & 85 & 50.3 & 200.0 \\
\hline Ganz River & 18 & 10.7 & 247.9 \\
\hline Pukl & 5 & 3.0 & 311.7 \\
\hline A & 4 & 2.4 & 164.3 \\
\hline B & 2 & 1.2 & 381.8 \\
\hline C & 13 & 7.7 & 109.3 \\
\hline D & 3 & 1.8 & 93.4 \\
\hline Tsenga gaima & 4 & 2.4 & 451.6 \\
\hline Yambina & 3 & 1.8 & 171.2 \\
\hline Mbukl & 7 & 4.1 & 148.6 \\
\hline Repeng & 1 & 0.6 & 175.6 \\
\hline Dom gaima & 5 & 3.0 & 76.3 \\
\hline Unknown & 1 & 0.6 & 291.7 \\
\hline Local & 18 & 10.7 & 186.0 \\
\hline TOTAL/AVERAGE & 169 & 100 & 215 \\
\hline
\end{tabular}

Source: Based on Burton (1984: 293-296).

Note: The means of axe identification were IR spectrum 42 per cent and hand inspection 58 per cent. 


\section{The age of the axe trade in the upper Wahgi}

Dating the appearance of traded axe stone at Kuk is of prime importance, but difficult to determine. Limiting factors include the greater representation of axes at house sites than in gardens and the greater likelihood that they can be dated more reliably there than elsewhere. For the axes listed in Table 21.4 here and those in Fullagar's list (Table 20.7 here), omitting the Phase 3 example as only a possibility, the association with houses predominates. In the Fullagar list the earliest date is later Phase 5, when the first houses appear in the swamp.

Burton's discussion of the chronology of traded axes excavated by Christensen at rockshelters in the Manim Valley is important in this context, and unique (1984: 227-228, Tables 10.7 and 10.8, Fig. 10.15; cf. Chapter 14 here). The rockshelters in question are within the wider Wurup area of Christensen's archaeological reconnaissance and axe collecting of the 1970s. Burton bases his argument on two of four excavated sites, Etpiti and Kamapuk, where sufficient fragments of polished stone were present to make a statistical exercise worthwhile. The finds were sorted by inspection into two groups: those that were evidently from quarries; and those made of stone from local sources or of unknown provenance. Most of the pieces from recognised quarries were from Tuman axes or a Jimi Valley source. Three Kamapuk fragments and one from Etpiti were tested spectroscopically.

Burton (1984: Table 10.8) gives the quarried stone for each site as a percentage by weight of all polished stone by excavated level and then smooths the percentages with a simple running average calculation. Both sets of values appear in Figure 21.5 here. From these data, the balance of probability is that quarried stone entered the archaeological record of the Wurup Valley sometime between about 2500 and 1000 years $\mathrm{ago}^{1}$. Following the running averages, the proportion of quarried stone at both sites rose from zero before this period to almost 100 per cent of the assemblages by the end of it. This conclusion (Burton 1984) was based on imperfect data. Then, and now, it requires confirmation from wellstratified sites in the region. Nonetheless, it is on this particular evidence that the Wahgi wealth economy, of which the axe trade is a product, can be said to date back to the Phase 4 period, between 2000 and 1100 years ago (see Chapter 14).
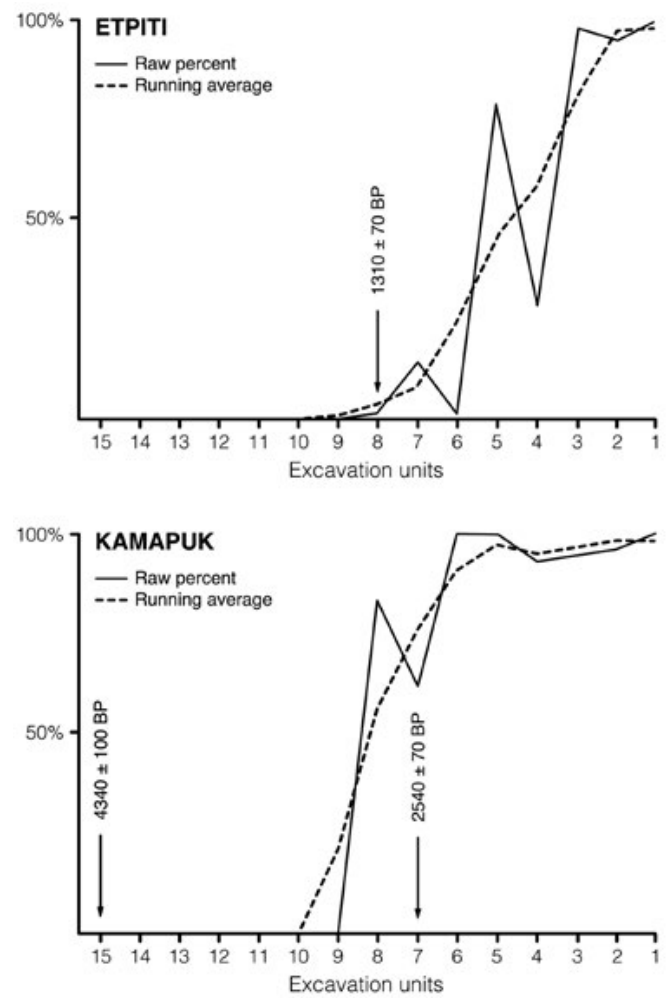

Figure 21.5 Manim Valley rockshelters: quarried stone as a percentage by weight of all axe stone. Source: Drawing by Harrison Pitts after Burton (1984: Fig. 10.15), reproduced with permission.

1 Golson and Gardner (1990: 404) note that Burton originally said 'between about 2500 and 1500 years ago' (1984: 228). As the rise in quarried stone at Etpiti is steepest in Level 6, and whereas the 1310 \pm 70 (ANU-1324) radiocarbon date for this site is from Level 8, the broader range is preferred (cf. Burton 1989: 256). 


\title{
Appendix 21.1: Petrography, Geochemistry and Chronology of Stone Artefact K/77/S34: A Probable Rim Fragment from a Stone Mortar
}

\author{
Noreen Evans and Brent McInnes
}

\section{Petrographic description}

On 1 November 1999, David Ellis gave Jack Golson a brief report on samples from four associated pieces of stone excavated at Kuk Swamp, one of them a proposed mortar rim. He described this as comprising a fine-grained equigranular volcanic rock of broadly intermediate composition. A most unusual feature is the abundance of weakly aligned apatite laths (phenocrysts; see Fig. A21.1). The dominant phenocryst phase is well-shaped plagioclase feldspar grains. Minor pyroxene and opaque oxide are also present. The finer-grained groundmass has been partly replaced by secondary (green) minerals, but unaltered groundmass is still preserved. Such distinctive grains of apatite, which crystallised early from the magma, are not typically associated with igneous rocks containing groundmass quartz.

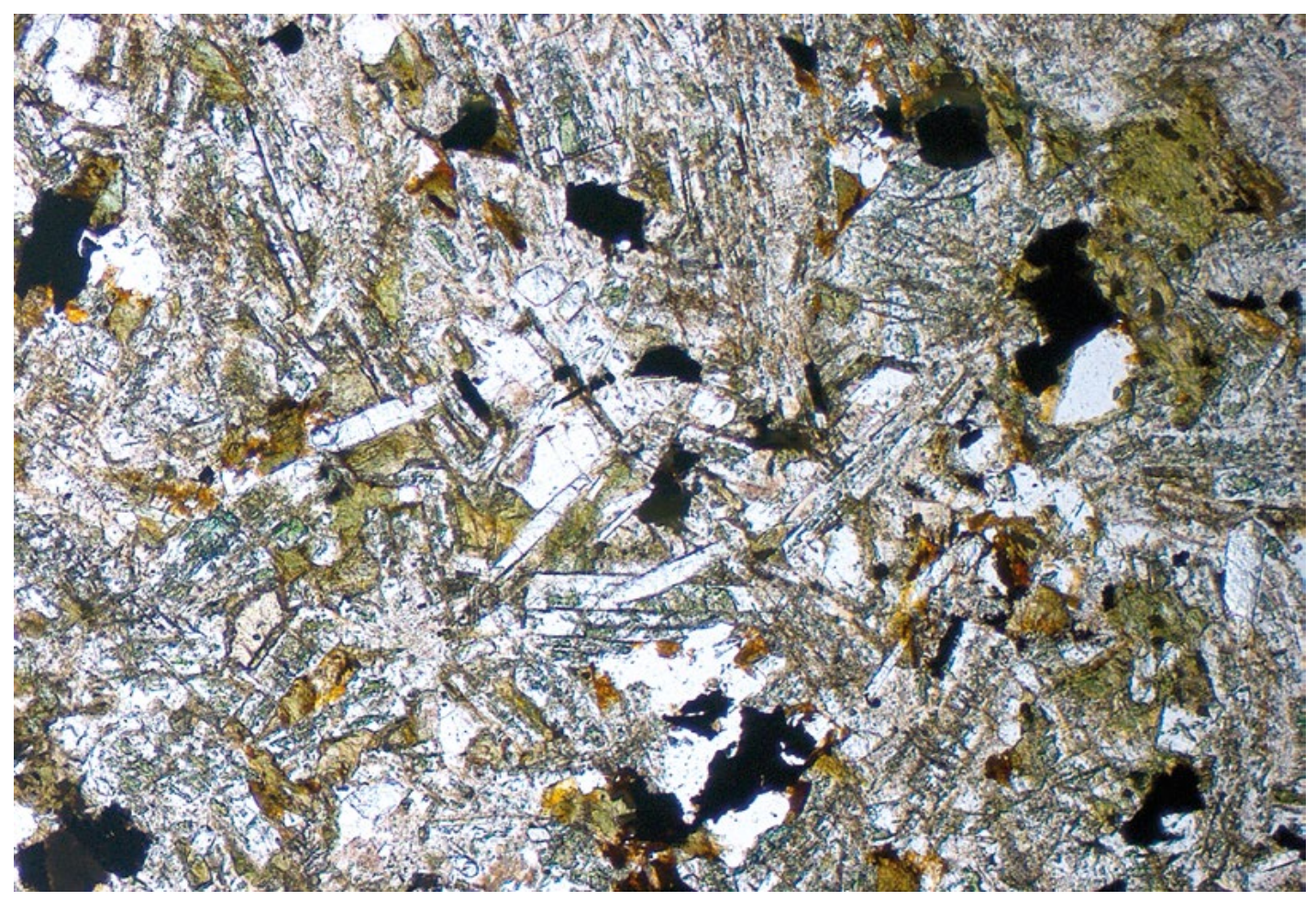

Figure A21.1 Photomicrograph of tholeiitic basalt viewed in plane polarised light.

The image shows aggregations of altered feldspar laths (cloudy) intergrown with mafic minerals (clinopyroxene altered to chlorite and amphibole), titanomagnetite (black) and acicular apatite crystals (clear). The field of view is $2.4 \mathrm{~mm}$.

Source: Photograph by Brent Mclnnes. 


\section{Details of petrography}

The following information comes from Doug Mackenzie, who submitted a final report to Golson on 2 February 2000 following his examination of a thin section from K/77/S34 by polarising petrographic microscope. He described the rock as being an andesite. However, as discussed below, Evans, McInnes and Ellis subsequently concluded that it was a basalt.

\section{Observations}

The rock is a metamorphosed and/or intensely altered, apatite-rich hornblende- 2 pyroxene quartz tholeiite or tholeiitic andesite made up of a mixture of primary and secondary minerals.

The primary minerals (crystallised from magma) are:

- Plagioclase (60 per cent by volume), composition $\mathrm{An}_{30-47}$, intensely altered to sericite/illite, chlorite and epidote

- Magnetite + ilmenite/Ti-rich magnetite (10 per cent by volume)

- Apatite (5 per cent by volume), long prisms

- Clinopyroxene (5 per cent by volume), very pale brown augite

- Quartz (3 per cent by volume)

- Hornblende (3 per cent by volume), medium pale green to greenish brown, largely altered to chlorite

- Orthopyroxene ( $<1$ per cent by volume), very pale pink to faint green/colourless, partly altered to chlorite

- Biotite (<1 per cent by volume), deep yellowish brown to straw, partly altered to chlorite

The secondary minerals (crystallised in solid state) are:

- Chlorite (8 per cent by volume), bluish green to yellowish green

- Sericite/illite (2 per cent by volume), colourless

- Lawsonite (2 per cent by volume), pinkish brown to deep green or blue green

- Epidote (1-2 per cent by volume)

- Titanite (<1 per cent by volume), dark brown; associated with magnetite (ilmenite)

\section{Interpretation}

Mackenzie described this as a rock of unusual mineralogy. The abundance and coarse grain size of the apatite $\left[\mathrm{Ca}_{5}\left(\mathrm{PO}_{4}\right)_{3}(\mathrm{OH}, \mathrm{F}, \mathrm{Cl})\right]$ and the presence of biotite are characteristics that he had not observed before, nor was aware of, in any rock from mainland New Guinea. He went on to comment on the results of the geochemical analysis, to which we now turn.

\section{Geochemistry}

David Ellis had emailed Golson on 7 December 1999 to say that the analysis of the geochemical composition of the rim sample had just been completed at The Australian National University (ANU). He headed his message 'Glum News'. This was because the sample had turned out to be an arc volcanic, a fractionated tholeiitic basalt, meaning that a specific source location could not be defined. He mentioned Doug Mackenzie saying to him with regard to the geochemical picture, that he had seen nothing like it from the Papua New Guinea (PNG) highlands.

On Christmas Eve, Ellis followed up with a second email giving major oxide and trace element geochemistry results (for the former see Table A21.1), and confirming their interpretation as characteristic of an evolved tholeiitic basalt that formed in an active plate margin where 
subduction occurs. In order to determine the likely source of such a rock, he said it would be necessary to do a literature survey of the distribution of tholeiitic series magmas within PNG, combined with isotopic dating to determine the age of crystallisation of the lava.

Table A21.1 Geochemical results for oxides from the mortar rim.

\begin{tabular}{|l|c|c|c|c|c|c|c|c|c|c|c|}
\hline Oxide & $\mathrm{SiO}_{2}$ & $\mathrm{TiO}_{2}$ & $\mathrm{Al}_{2} \mathbf{O}_{3}$ & $\begin{array}{l}\mathrm{Fe}_{2} \mathbf{O}_{3} \\
\text { (tot) }\end{array}$ & $\mathbf{M n 0}$ & $\mathbf{M g 0}$ & $\mathbf{C a 0}$ & $\mathrm{Na}_{2} \mathbf{O}$ & $\mathrm{K}_{2} \mathbf{0}$ & $\mathbf{P}_{2} \mathbf{O}_{5}$ & Total \\
\hline Concentration (\%) & 50.38 & 3.17 & 14.11 & 12.96 & 0.247 & 3.48 & 6.72 & 3.98 & 0.815 & 1.51 & 97.6 \\
\hline
\end{tabular}

Source: David Ellis 1999.

As things stood, we were left with Mackenzie's 2000 report conclusions, from the petrographic and geochemical data that we review here. Mackenzie offered three alternative explanations for the source of the stone of the Kuk mortar rim, which Golson (2000: 233-234) published in his paper on the subject:

1. that it is probably not of local (Mt Hagen) origin and unlikely to have come from elsewhere in mainland PNG, or from mainland Australia or the Torres Strait Islands, with the most likely source area in PNG itself being the islands running parallel to the east coast of New Ireland, or New Ireland itself, though admittedly the published geological information made this a remote possibility;

2. that the raw material is a 'foreign' rock (xenolith) that was enclosed in a very different rock type and 'freed' by subsequent weathering, given that the different rock type could exist in the crust beneath the PNG highlands region and have been caught up in the magma erupted from a volcano like Mt Hagen. However, the scenario seemed to Mackenzie unlikely given the calculated size and weight of the mortar from which the rim had come, and therefore of the parent rock; and

3. that the raw material belonged to the Indonesian region (other than West Papua), perhaps Sarawak or Kalimantan, this being Mackenzie's favoured option, though he admitted that he did not have relevant information to be more specific.

At the end of his report Mackenzie mentioned the possibility of dating the rock to help to resolve the question of origin. Ellis had also recommended this in his December 1999 email to Golson, when reporting on the results of the geochemical analysis of the rim fragment.

It is to this dating that we now turn.

\section{Thermochronology}

By this stage Golson was, through David Ellis, in touch with Brent McInnes and Noreen Evans at CSIRO Exploration and Mining, North Ryde, Sydney, currently of Curtin University, Perth. He was interested to learn about the new radiometric technique of $(\mathrm{U}-\mathrm{Th}) / \mathrm{He}$ thermochronometry, which was appropriate for dating the raw material of the Kuk mortar rim because it was rich in apatite. The aim of the dating was to narrow the search for the volcanic province where the parent rock originated. McInnes and Evans agreed to take on the task and by mid-2000 had produced results.

\section{Methods}

Apatite grains for (U-Th)/He thermochronology were selected under the microscope in order to avoid grains with cracks or U- and Th-rich mineral/fluid/gas inclusions that may contribute excess helium to the analysis. Grain measurements were taken for the calculation of an alpha 
correction factor (Ft; Farley, Wolf and Silver 1996), and every effort was made to select grains with a diameter larger than 70 microns in order to maximise helium gas values and minimise the Ft correction.

Helium was thermally extracted from a weighed aliquot of apatite, loaded into platinum microcrucibles and heated using a $1064 \mathrm{~nm}$ Nd-YAG laser. ${ }^{4} \mathrm{He}$ abundances were determined by isotope dilution using a pure ${ }^{3} \mathrm{He}$ spike, calibrated daily against an independent ${ }^{4} \mathrm{He}$ standard tank. The uncertainty in the sample ${ }^{4} \mathrm{He}$ measurement is $<1$ per cent.

For degassed apatite, the $\mathrm{U}$ and Th contents were determined by isotope dilution using ${ }^{235} \mathrm{U}$ and ${ }^{230} \mathrm{Th}$ spikes. $25 \mu \mathrm{l}$ of a 50 per cent (by volume; approximately $7 \mathrm{M}$ ) $\mathrm{HNO}_{3}$ solution containing approximately $15 \mathrm{ppb}^{235} \mathrm{U}$ and $5 \mathrm{ppb}^{230} \mathrm{Th}$ was added to each sample. The apatite was digested in the spiked acid for at least 12 hours to allow the spike and sample isotopes to equilibrate. Standard solutions containing the same spike amounts as the samples, in addition to $25 \mu \mathrm{l}$ of a standard solution containing $27.56 \mathrm{ppb} U$ and $28.38 \mathrm{ppb} T \mathrm{Th}$, were treated identically, as was a series of unspiked reagent blanks (just $25 \mu \mathrm{l}$ of the 50 per cent $\mathrm{HNO}_{3}$ ). Prior to analysis $250 \mu \mathrm{l}$ of MilliQ water was added on a Perkin Elmer 5000 mass spectrometer (at the University of Technology, Sydney). $U$ and Th isotope ratios were measured to a precision of $<2$ per cent. Overall the (U-Th)/He thermochronology method utilised has a precision of 2.5 per cent for apatite, based on multiple age determinations $(\mathrm{n}=70)$ of Durango standard which produce an average age of 31.5 $\pm 1.6(2 \sigma)$ million years (Ma). More detail can be found in Evans et al. 2005 .

\section{Results}

(U-Th)/He thermochronology on the apatite from the mortar rim sample yielded reproducible ages of $2.72 \pm 0.13$ and $2.61 \pm 0.38 \mathrm{Ma}$ as shown in Table A21.2 below. This puts it in the Late Pliocene, older than the local Hagen Volcanics, which formed less than two million years ago in the Early Pleistocene.

Table A21.2 Apatite (U-Th)/He dating of the mortar rim fragment.

\begin{tabular}{|l|c|c|c|c|c|c|c|}
\hline & He (ncc/g) & U (ppm) & Th $(\mathbf{p p m})$ & Th/U & Ft & Corrected Age (Ma) & $\pm 2 \sigma$ \\
\hline $\mathrm{K} / 77 / \mathrm{S} 34-1$ & 483 & $1.14 \pm 0.02$ & $3.72 \pm 0.07$ & 3.37 & 0.73 & 2.72 & 0.13 \\
\hline $\mathrm{K} / 77 / \mathrm{S} 34-2$ & 850 & $2.18 \pm 0.03$ & $7.60 \pm 0.14$ & 3.60 & 0.68 & 2.61 & 0.38 \\
\hline
\end{tabular}

Source: GeoHistory Facility, John de Laeter Centre, Curtin University, Perth.

Note: Ft is the alpha correction applied to the helium content of the sample to account for daughter product lost from the crystals during radioactive decay (Farley et al. 1996).

\section{Conclusions}

On the basis of the petrographic and geochemical data discussed in the first part of this Appendix, Mackenzie ruled out mainland New Guinea as the source of the raw material of the Kuk mortar rim. He suggested New Ireland and the string of islands along its east coast as a remote possibility, but favoured Indonesian regions like Sarawak and Kalimantan (but not West Papua). The thermochronological data that we have reviewed by no means points categorically to a PNG origin, but the dating of the rim material to the Late Pliocene makes it a possibility. As Hugh Davies wrote in an email to Golson in mid-2001 (Kuk archive 2001), 'we simply don't know enough about the compositions of the Late Pliocene volcanics in PNG to confidently exclude a source from within PNG'.

There is other recent evidence that might indirectly support the Davies' conclusion. Fieldwork conducted by Brent McInnes in north Sumatra in 2001 uncovered andesitic dykes exposed in a riverbed. Basic petrography revealed acicular, elongated apatite crystals, similar to those 
observed in the mortar rim sample. The particular crystal habit exhibited by both samples is likely to originate when intermediate magma cools quickly, such as when magma is injected as a dyke into the crust. While such distinct rock material has not been reported in PNG, it may well have been overlooked by geologists not interested in quarry material. It is probable that this type of rock material was more resistant to erosion than surrounding country rock, and may have been exposed in a riverbed or valley slope. The relative hardiness of the material, coupled with its non-brittle alkaline-phosphatic nature would have meant that it was easier to work with than other rocks available in the local environment. 
This text is taken from Ten Thousand Years of Cultivation at Kuk Swamp in the Highlands of Papua New Guinea, edited by Jack Golson, Tim Denham, Philip Hughes, Pamela Swadling and John Muke, published 2017 by ANU Press, The Australian National University, Canberra, Australia. 